\title{
Metal vapour derived supported rhodium nanoparticles in the synthesis of $\beta$-lactams and $\beta$-lactones derivatives
}

\author{
Laura Antonella Aronica $^{\mathrm{a}, *}$, Anna Maria Caporusso ${ }^{\mathrm{a}}$, Claudio Evangelisti ${ }^{\mathrm{a}}$, Maria Botavina ${ }^{\mathrm{b}}$, \\ Gabriele Alberto $^{\mathrm{b}}$, Gianmario Martra ${ }^{\mathrm{b}}$ \\ a Dipartimento di Chimica e Chimica Industriale, Università di Pisa, Via Risorgimento 35, 56126 Pisa, Italy \\ ${ }^{\mathrm{b}}$ Dipartimento di Chimica IFM and NIS Centre of Excellence, Università di Torino, Via P. Giuria 7, 10125 Torino, Italy
}

\section{A R T I C L E I N F O}

\section{Article history:}

Received 20 May 2011

Accepted 8 November 2011

\section{Keywords:}

$\beta$-Lactones

$\beta$-Lactams

Silylcarbocyclisation

Supported rhodium nanoparticles

Metal vapour synthesis

Catalysis

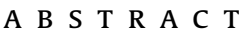

Functionalised $\beta$-lactones and $\beta$-lactams were prepared starting from propargyl alcohols and propargyl tosyl amides by means of efficient silylcarbocyclisation reactions catalysed by rhodium nanoparticles derived from mesitylene-solvated Rh atoms (Metal Vapour Synthesis technique, MVS) and deposited on inorganic ( $\mathrm{C}, \gamma-\mathrm{Al}_{2} \mathrm{O}_{3} \mathrm{Fe}_{2} \mathrm{O}_{3}$ ) and organic matrices (PBI). All the MVS supported nanoclusters resulted more active than the analogous commercial $\mathrm{Rh} / \mathrm{C}$ and $\mathrm{Rh} / \gamma-\mathrm{Al}_{2} \mathrm{O}_{3}$, as well as homogeneous $\mathrm{Rh} \mathrm{C}_{4}(\mathrm{CO})_{12}$ used as reference catalyst. In particular, metal vapour derived $\mathrm{Rh} / \mathrm{C}$ afforded the $\beta$-lactones and $\beta$-lactams in high yields and chemoselectivity. Preliminary investigations on the nature of the real active metal species involved in the catalytic process showed that rhodium $(0)$ naked nanoparticles are leached by the support. The high catalytic activity encountered with $\mathrm{Rh} / \mathrm{C}$ could be ascribed to the easy leaching of metal nanoparticles from carbon into solution. Indeed, the presence of a more polar matrix determined a minor catalytic efficiency probably due to a stronger interaction between the metal and the support. Therefore MVS Rh/C species represents a source, stable with ageing at room temperature, of highly active metal nanoparticles.
\end{abstract}

(C) 2011 Elsevier B.V. All rights reserved.

\section{Introduction}

Four-membered monocyclic heterocycles have received little interest from the chemical community compared to the higher homologous counter parts. Between $\beta$-lactams and $\beta$-lactones, the greatest attention was obviously paid to the first ones (also called azetidine-2-ones) since the $\beta$-lactam ring is the key of one of the most widely employed class of antibacterial agents, the $\beta$-lactam antibiotics which are distinguished by good tolerance and therapeutic safety (e.g. Tigemonam ${ }^{\circledR}$ ) [1-5]. Among $\beta$-lactams, the $\alpha$ methylene- $\beta$-lactam unit is a commune structural feature included in potent $\beta$-lactamase inhibitors such as asparenomycins and penicillanic acids [6-17].

On the contrary to what reported for $\beta$-lactams, $\beta$-lactones ( 2 oxetanones) have only recently emerged as important synthetic targets. Indeed, they have been studied as enzymes inhibitors [18-29] and have been tested in the treatment of infections generated by bacteria and viruses (i.e. human cytomegalovirus, human herpesvirus and Karposis's sarcoma herpesvirus) [30-32]. In the field

\footnotetext{
* Corresponding author. Tel.: +39 (0)502219274; fax: +39 (0)502219260

E-mail address: aronica@dcci.unipi.it (L.A. Aronica).
}

of $\beta$-lactones, $\alpha$-methylene- $\beta$-lactones (3-methyleneoxetan-2-ones) were nearly unknown molecules until the late '80s. This is especially puzzling in view of the high degree of functionality contained in this heterocyclic system, which should lend itself to diversified synthetic applications [33-38].

Considering the synthetic value of $\beta$-lactams [39-41] and $\beta$-lactones [42], it is not surprising that many methods have been developed to achieve selective and efficient syntheses [43-45]. In particular, in 1990 Matsuda and co-workers [46] reported the first example of rhodium-catalysed silylcarbocyclisation of propargyl alcohols that generated $\alpha$-(trialkylsilyl)methylene- $\beta$-lactones in good yields, provided that DBU and a suitable hydrosilane were used (Scheme 1, route 1). Otherwise, silylformylation by-products, derived from the direct addition of $\mathrm{CO}$ and silane to the triple bond, may be observed (Scheme 1, route 3 ).

A year later the same group published [47] the first application of the silylcarbocyclisation process to the synthesis of silylated $\alpha$ methylene- $\beta$-lactams (Scheme 1 , route 2 ) starting from easily available propargylamine derivatives.

The silylcarbocyclisation reactions are generally performed in the presence of a catalytic amount of rhodium based homogeneous species such as $\mathrm{Rh}_{4}(\mathrm{CO})_{12}[38,48-52]$. No examples of the use of heterogeneous catalysts are known though they would allow 


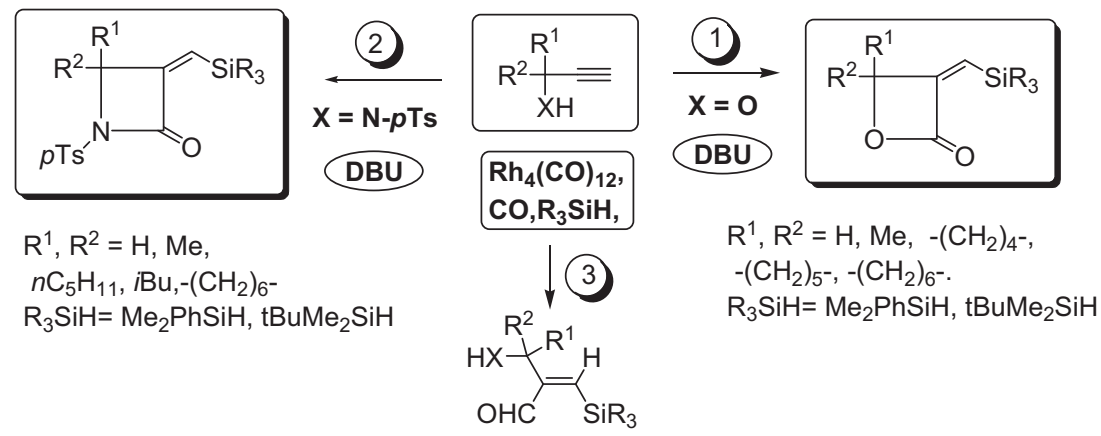

Scheme 1.

simpler recovery and easier purification of the product, possible recycle of the catalyst and could assure a higher thermal stability of the catalytic species.

In the field of heterogeneous catalysis, the use of supported nanoparticles represents a modern approach which takes advantage from the high reactivity of very small metal clusters. Innovative procedures have been developed to attain effective tailoring of the size of the metal particles. Successful results have been obtained employing chemical vapour deposition and thermal, photochemical, or sonochemical decomposition of organometallic complexes on a suitable matrix. All these methods afford the metal nanoparticles with good reproducibility and narrow size distributions, but the precursors, i.e. the organometallic species, may not always be easily available.

An alternative versatile methodology is the so-called Metal Vapour Synthesis (MVS) technique which is based on the formation of "solvated metal atoms" (SMA), i.e. solvent stabilized metal nanoclusters obtained by co-condensation of metal vapours with organic ligands (mesitylene, toluene, acetone...). SMA have been employed as catalytic precursors in a wide range of reactions such as hydrogenation [53-57], hydroformylation [58-60], hydrosilylation [61-66] and carbon-carbon coupling [67-70].

Recently we have reported a qualitative evaluation of the catalytic properties of rhodium supported nanoparticles, obtained from $\mathrm{Rh} /$ mesitylene SMA solutions, in the silylcarbocyclisation of propargyl amines and alcohols [71].

Prompted by the promising data obtained, we decided to deeply investigate the factors that influence the catalytic performances of rhodium SMA derived species in synthesis of $\alpha$-methylene- $\beta$-lactams and $\alpha$-methylene- $\beta$-lactones. Since the silylformylation is a common side reaction of the silylcarbocyclisation process, for this paper we started our investigation testing the activity of rhodium supported nanoparticles in the silylformylation of simple and functionalised acetylenes. As a matter of fact, we have previously described [72] that solvated rhodium atoms, prepared by the metal vapour synthesis technique, promoted the silylformylation reaction of variously substituted alkynes with catalytic activities comparable with and even higher than more common species such as $\mathrm{Rh}_{4}(\mathrm{CO})_{12}$.

Subsequently, the activity of the supported Rh-SMA was exhaustively evaluated in the silylcarbocyclisation of propargyl derivatives.

\section{Results and discussion}

\subsection{Preparation of the catalysts}

Rhodium nanoparticles were generated by means of the MVS technique. According to previously described experimental procedures [73], Rh and mesitylene were vaporised under vacuum and deposited on the frozen walls $\left(-196^{\circ} \mathrm{C}\right)$ of a glass reactor, generating a red-brown matrix. During the warm-up stage from -196 to $-30^{\circ} \mathrm{C}$ the matrix melted, and nucleation and growth processes of the metal particles took place leading to rhodium $(0)$ nanoclusters weakly stabilized by the mesitylene molecules, the socalled "solvated metal atoms" (SMA) (Scheme 2, steps 1 and 2) [74]. The obtained $\mathrm{Rh} /$ mesitylene solution was employed directly as source of metal nanoparticles in the carbonylation reactions.

The supported catalysts $\mathrm{Rh} / \mathrm{C}$ and $\mathrm{Rh} / \gamma-\mathrm{Al}_{2} \mathrm{O}_{3}$ (Table 1 entries 3 and 4 ) were prepared by simple addition of the $\mathrm{Rh} / \mathrm{SMA}$ to the chosen supports till decolourisation of the solution occurred, which was indicative of the complete deposition of the rhodium particles on the matrices (Scheme 2, step 3) [74]. The catalysts thus obtained were ready for use without any pre-activation step.

The morphology of all the supported nanoparticles was investigated by means of high resolution transition electron microscopy (HR-TEM) (Fig. 1 and Table 1). The particle size distribution and the mean diameter of the nanoparticles of $\mathrm{Rh} / \mathrm{C}$ and $\mathrm{Rh} / \gamma-\mathrm{Al}_{2} \mathrm{O}_{3}$ prepared via MVS technique were compared with those of commercially available samples. As reported in Table 1 (entries 1 and 2) and in Fig. 1(a) and (b), the analysis of the metal particles of the commercial $\mathrm{Rh} / \mathrm{C}$ and $\mathrm{Rh} / \gamma-\mathrm{Al}_{2} \mathrm{O}_{3}(5 \% \mathrm{Rh} \mathrm{w} / \mathrm{w})$ systems showed the presence of rhodium clusters with a broad size distribution lying in the $1.5-14 \mathrm{~nm}$ range and average diameters of 3.5 and $7.1 \mathrm{~nm}$.

The HR-TEM analysis of the corresponding MVS catalysts (Fig.1(c) and (d), Table 1, entries 3 and 4) indicated the presence of

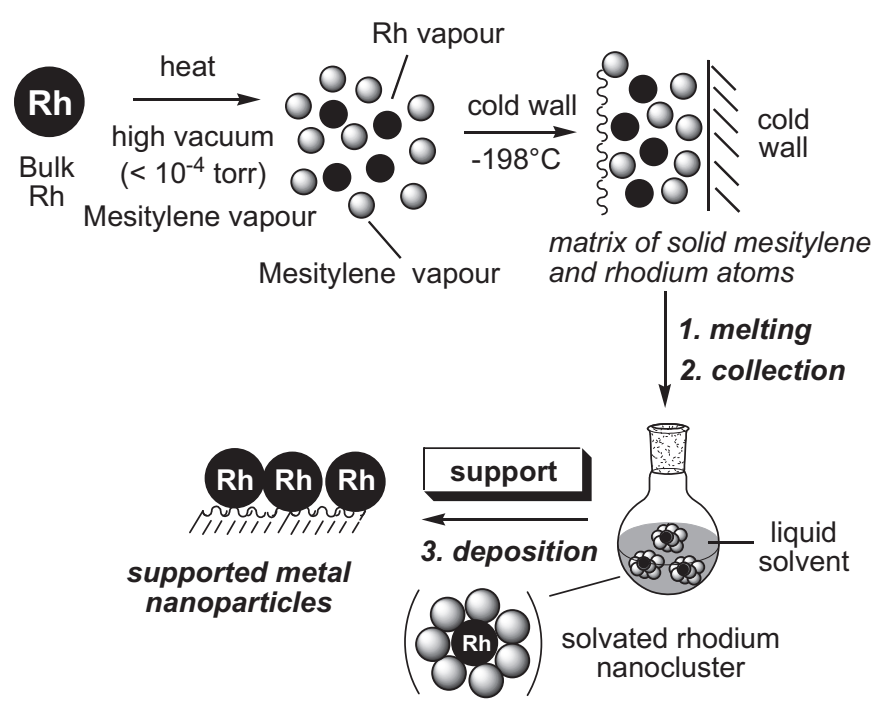

Scheme 2. 
Table 1

Rhodium catalysts.

\begin{tabular}{llllll}
\hline No. & Catalyst & $\begin{array}{l}\text { Metal } \\
\text { loading } \\
\% \mathrm{w} / \mathrm{w}\end{array}$ & Type & $\begin{array}{l}d_{\mathrm{m}} \text { (mean } \\
\text { diameter, nm) }\end{array}$ & $\begin{array}{l}\text { Particles size } \\
\text { distribution }(\mathrm{nm})^{\mathrm{a}}\end{array}$ \\
\hline 1 & $\mathrm{Rh} / \mathrm{C}$ & 5 & Comm. & 3.5 & $1.5-6.0$ \\
2 & $\mathrm{Rh} / \mathrm{Al}_{2} \mathrm{O}_{3}$ & 5 & Comm. & 7.1 & $1.5-14.0$ \\
3 & $\mathrm{Rh} / \mathrm{C}$ & 1 & MVS & 2.4 & $1.2-4.4$ \\
4 & $\mathrm{Rh} / \mathrm{Al}_{2} \mathrm{O}_{3}$ & 1 & MVS & 2.1 & $1.0-4.0$ \\
5 & $\mathrm{Rh} / \mathrm{Fe}_{2} \mathrm{O}_{3}$ & 0.98 & MVS & $\leq 1$ & - \\
6 & $\mathrm{Rh} / \mathrm{PBI}$ & 0.98 & MVS & 2.2 & $1.7-3.2$ \\
\hline
\end{tabular}

a Determined by HR-TEM analysis.

supported rhodium particles smaller than the commercial samples, having a size distribution in a narrower range, $1.0-4.4 \mathrm{~nm}$, and mean diameters of 2.4 and $2.1 \mathrm{~nm}$, respectively. In these cases, moreover, two additional considerations have to be made: the former is that HR-TEM does not have a high sensitivity in revealing particles smaller than $1 \mathrm{~nm}$ in size, and the latter is that the occurrence of aggregation phenomena of sub-nanometric metal particles under the electron beam during HR-TEM observation cannot be excluded. As a consequence the real mean size of MVS Rh particles could be even smaller.

In order to investigate the effect of a highly polar inorganic or organic matrix on the reactivity and selectivity of the metal nanoclusters, two more supported rhodium species were prepared starting from the $\mathrm{Rh} / \mathrm{SMA}$ solution: $\mathrm{Rh} / \mathrm{Fe}_{2} \mathrm{O}_{3}(0.98 \% \mathrm{w} / \mathrm{w})$ and

a

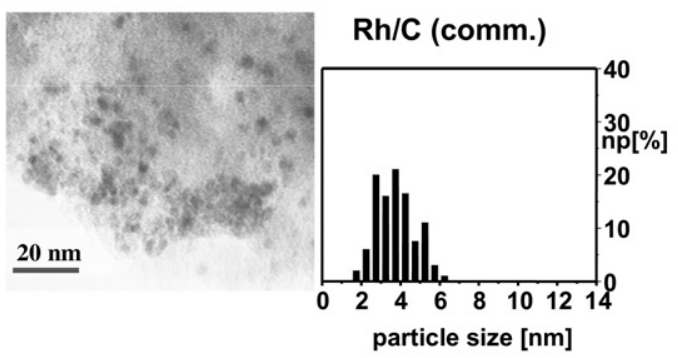

C
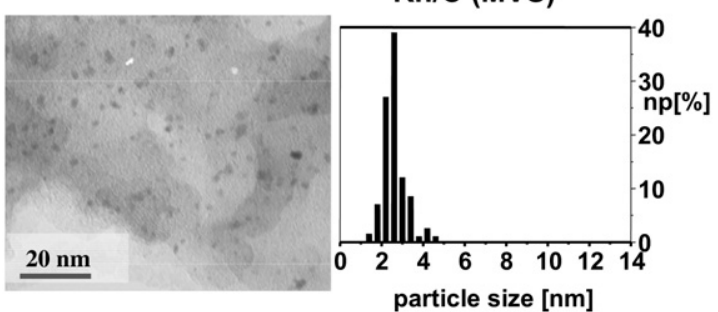

e

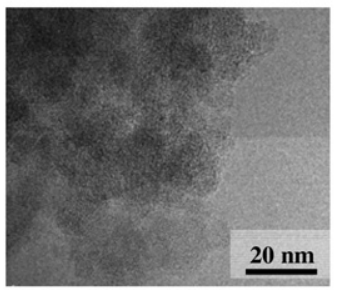

\section{$\mathrm{Rh} / \mathrm{Fe}_{2} \mathrm{O}_{3}$ (MVS)}

Particle size below the the detection limit of TEM (ca. $1.0 \mathrm{~nm}$ )<smiles>Cc1cccc(-c2nc3cc(-c4ccc5[nH]c(C)nc5c4)ccc3[nH]2)c1</smiles>

Fig. 2. Structure of polybenzoimidazole (PBI).

Rh/PBI (polybenzoimidazole, Fig. 2) [75], (0.98\% w/w), (Fig. 1(e) and (f), Table 1, entries 5 and 6).

For Rh/PBI a statistical evaluation of the size of the Rh particles was carried out and very narrow particle size distributions were obtained: $1.7-3.2 \mathrm{~nm}$. Rh particles were rather small and well dispersed with a more abundant population around $2.2 \mathrm{~nm}$ (Table 1, entry 6 and Fig. 1(f)).

As far as $\mathrm{Rh} / \mathrm{Fe}_{2} \mathrm{O}_{3}$ the size of the $\mathrm{Rh}$ particles could not be determined since the size of the particles resulted near or less than the detection limit of the TEM technique $-1 \mathrm{~nm}$. However, the metal particles seemed to be well dispersed on the support surface.

\subsection{Silylformylation of terminal alkynes}

The catalytic activity of MVS and commercial supported rhodium species was initially tested in the silylformylation reaction

b

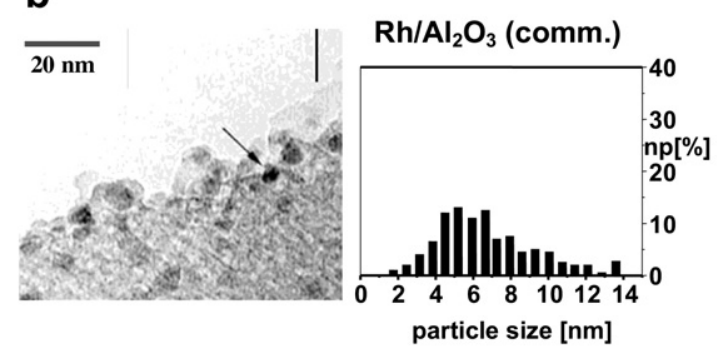

d

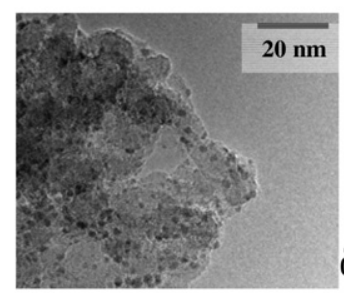

$\mathrm{Rh} / \mathrm{Al}_{2} \mathrm{O}_{3}$ (MVS)

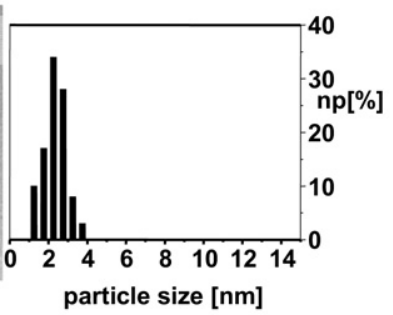

f

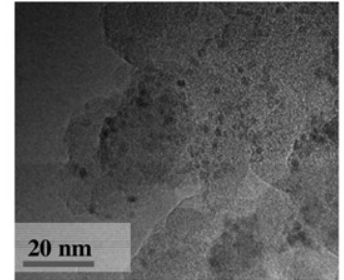

Rh/PBI (MVS)

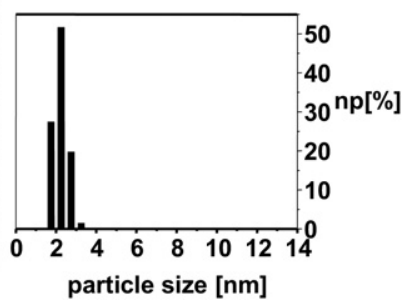

Fig. 1. HR-TEM micrographs and histograms of particle size distributions of rhodium supported nanoparticles: (a) Rh/C (comm.); (b) $\mathrm{Rh} / \gamma-\mathrm{Al}_{2} \mathrm{O}_{3}$ (comm.); (c) Rh/C (MVS); (d) $\mathrm{Rh} / \gamma$ $\mathrm{Al}_{2} \mathrm{O}_{3}$ (MVS); (e) $\mathrm{Rh} / \mathrm{Fe}_{2} \mathrm{O}_{3}$ (MVS); (f) $\mathrm{Rh} / \mathrm{PBI}$ (MVS). 
of 1-hexyne (1a) and dimethylphenylsilane (2a) chosen as model substrates (Scheme 3, Table 2).

In a typical experiment, equimolar amounts of the alkyne and $\mathrm{Me}_{2} \mathrm{PhSiH}$ were reacted in the presence of $0.1 \mathrm{~mol} \%$ of the rhodium catalyst with respect to the silane, in a $25 \mathrm{~mL}$ stainless steel autoclave pressurised to $10 \mathrm{~atm}$ of carbon monoxide. The reaction mixture was stirred at room temperature for the times reported in Table 2 (entries 1-8).

All the MVS rhodium species were able to catalyse the silylformylation of 1-hexyne with high chemo- and stereoselectivity, affording (Z)-1-(dimethylphenylsilyl)-formyl-1-hexene 3aa exclusively.

The specific activity of the catalysts SA (calculated as [mmol(silane)/mgat $\mathrm{Rh}$-time of reaction(h)] conv.\%) resulted however dependent on the nature of the support.

While both commercial $\mathrm{Rh} / \mathrm{C}$ and $\mathrm{Rh} / \gamma-\mathrm{Al}_{2} \mathrm{O}_{3}$ where almost inert (Table 2, entries 7 and 8 ), the supported MVS catalysts showed appreciable to excellent SA (Table 2, entries 3-6). In particular the catalytic activity of Rh/C (MVS) was comparable to the Rh/mesitylene precursor solution and even higher than $\mathrm{Rh}_{4}(\mathrm{CO})_{12}$ (Table 2 , entry 3 vs. entries 2 and 1 ), commonly used as homogeneous catalyst in this reaction [72].

The particle sizes obtained from the HR-TEM analysis (Table 1, entries 1,2 vs. 3,4 ) can possibly account for the different catalytic behaviour: the smaller the nanoparticles are, the higher the specific activity is (Table 2 entries 3,4 vs. 7,8). Moreover, the presence of the carbon instead of alumina as inert support determines an improvement in the catalyst efficiency, as it is evident from the data reported in Table 2 (entry 3 vs. 4 ). This effect could be reasonably related to the polarity of $\gamma-\mathrm{Al}_{2} \mathrm{O}_{3}$ which could cause an increased stabilization of rhodium particles and a subsequent reduction of
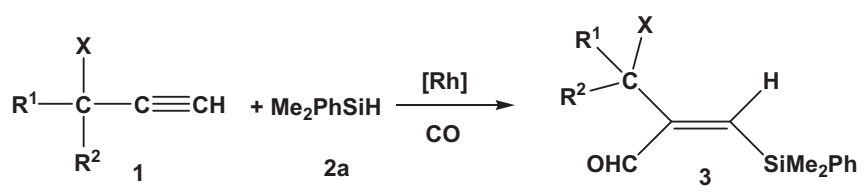

Scheme 3.

Table 2

Rhodium catalysts in the silylformylation of terminal alkynes.

\begin{tabular}{|c|c|c|c|c|c|c|c|c|c|c|}
\hline Entry & 1 & $\mathrm{R}^{1}$ & $\mathrm{R}^{2}$ & $\mathrm{X}$ & [Rh] & $t(\mathrm{~h})$ & 3 & $\begin{array}{l}\text { Conv. } \\
(\%)^{\mathrm{a}}\end{array}$ & $\begin{array}{l}\text { Sel. }^{\mathrm{a}} \\
(\%)\end{array}$ & $\mathrm{SA}^{\mathrm{b}}$ \\
\hline $1^{\mathrm{c}}$ & $\mathbf{a}$ & $n$-Pr & $\mathrm{H}$ & $\mathrm{H}$ & $\mathrm{Rh}_{4}(\mathrm{CO})_{12}{ }^{\mathrm{d}}$ & 6 & aa & 98 & 96 & 41 \\
\hline $2^{c}$ & $\mathbf{a}$ & $n-\operatorname{Pr}$ & $\mathrm{H}$ & $\mathrm{H}$ & $\mathrm{Rh} /$ mesitylene $\mathrm{d}^{\mathrm{d}, \mathrm{e}}$ & 6 & aa & 91 & 92 & 152 \\
\hline $3^{c}$ & $\mathbf{a}$ & $n-\operatorname{Pr}$ & $\mathrm{H}$ & $\mathrm{H}$ & $\mathrm{Rh} / \mathrm{C}(\mathrm{MVS})^{\mathrm{e}}$ & 6 & aa & 81 & 94 & 135 \\
\hline $4^{c}$ & $\mathbf{a}$ & $n-\operatorname{Pr}$ & $\mathrm{H}$ & $\mathrm{H}$ & $\mathrm{Rh} / \gamma-\mathrm{Al}_{2} \mathrm{O}_{3}(\mathrm{MVS})^{\mathrm{e}}$ & 6 & aa & 62 & 98 & 103 \\
\hline $5^{c}$ & $\mathbf{a}$ & $n-\operatorname{Pr}$ & $\mathrm{H}$ & $\mathrm{H}$ & $\mathrm{Rh} / \mathrm{Fe}_{2} \mathrm{O}_{3}(\mathrm{MVS})^{\mathrm{e}}$ & 6 & aa & 43 & 97 & 72 \\
\hline $6^{c}$ & $\mathbf{a}$ & $n-\operatorname{Pr}$ & $\mathrm{H}$ & $\mathrm{H}$ & $\mathrm{Rh} / \mathrm{PBI}(\mathrm{MVS})^{\mathrm{e}}$ & 6 & aa & 41 & 96 & 68 \\
\hline $7^{c}$ & $\mathbf{a}$ & $n-\operatorname{Pr}$ & $\mathrm{H}$ & $\mathrm{H}$ & $\mathrm{Rh} / \gamma-\mathrm{Al}_{2} \mathrm{O}_{3}$ (comm.) & 8 & aa & 0 & 0 & - \\
\hline $8^{c}$ & $\mathbf{a}$ & $n-\operatorname{Pr}$ & $\mathrm{H}$ & $\mathrm{H}$ & $\mathrm{Rh} / \mathrm{C}(\mathrm{comm})$. & 8 & aa & 12 & 97 & 15 \\
\hline $9^{f}$ & b & Me & Et & $\mathrm{OH}$ & $\mathrm{Rh}_{4}(\mathrm{CO})_{12}$ & 24 & ba & 86 & 85 & 9 \\
\hline $10^{\mathrm{f}}$ & b & Me & Et & $\mathrm{OH}$ & $\mathrm{Rh} / \mathrm{C}(\mathrm{MVS})^{\mathrm{e}}$ & 24 & ba & 30 & 85 & 12 \\
\hline
\end{tabular}

${ }^{a}$ Determined by GLC and ${ }^{1} \mathrm{H}$ NMR spectroscopic analysis of the reaction mixture after work up.

b SA: [mmol(silane)/mgat Rh - time of reaction(h)] conv.\%.

c Reaction conditions: $2 \mathrm{mmol}$ of $\mathrm{Me}_{2} \mathrm{PhSiH}, 2 \mathrm{mmol}$ of 1 -hexyne, $2 \times 10^{-3} \mathrm{mmol}$ of Rh, $2 \mathrm{~mL}$ of toluene, rt, $10 \mathrm{~atm} \mathrm{CO}$; hydrosilylation by-products were detected by ${ }^{1} \mathrm{H}$ NMR spectroscopy.

d See Ref. [72].

e Catalysts prepared according to the metal vapour synthesis technique.

${ }^{f}$ Reaction conditions: $3 \mathrm{mmol}$ of $\mathrm{Me}_{2} \mathrm{PhSiH}, 3 \mathrm{mmol}$ of alkyne, $3 \times 10^{-3} \mathrm{mmol}$ of $\mathrm{Rh}, 3 \mathrm{~mL}$ of $\mathrm{CH}_{2} \mathrm{Cl}_{2}, 100{ }^{\circ} \mathrm{C}, 20 \mathrm{~atm} \mathrm{CO}$; small amounts of $(E)$-isomers were detected by ${ }^{1} \mathrm{H}$ NMR spectroscopy. reactivity. This observation was confirmed by using $\mathrm{Rh} / \mathrm{Fe}_{2} \mathrm{O}_{3}$ and $\mathrm{Rh} / \mathrm{PBI}$ as catalytic precursors (Table 2, entries 5 and 6). Indeed, in these cases an even lower conversion of the reagents (around 40\%) was observed.

The presence of a functional group such as $\mathrm{OH}$ (Table 2, entries 9 and 10) did not affect the reaction path: the supported Rh/C (MVS) promoted the formation of the functionalised aldehyde $\mathbf{3 b a}$ with good selectivity and specific activity similar to $\mathrm{Rh}_{4}(\mathrm{CO})_{12}$.

\subsection{Silylcarbocyclisation of propagyl alcohols: synthesis of $\beta$ - lactones}

At the beginning of this study a preliminary investigation on the reactivity of MVS rhodium catalysts in the silylcarbocyclisation of a monosubstituted propargyl alcohol was carried out (Scheme 4, Table 3, entries 1-5). The reactions were performed at $100{ }^{\circ} \mathrm{C}$ for $4 \mathrm{~h}$, employing $3 \mathrm{mmol}$ of hydrosilane, $3 \mathrm{mmol}$ of alkyne, $3 \times 10^{-3} \mathrm{mmol}$ of $\mathrm{Rh}, 3 \mathrm{~mL}$ of $\mathrm{CH}_{2} \mathrm{Cl}_{2}$ and $0.3 \mathrm{mmol}$ of DBU under $\mathrm{CO}$ atmosphere ( $30 \mathrm{~atm}$ ). Initially, $t-\mathrm{BuMe}_{2} \mathrm{SiH} \mathbf{2 b}$ was reacted with the alcohol since it is known that the silylcarbocyclisation reaction is favoured by the presence of bulky substituents on the reagents.

$\mathrm{Rh} /$ mesitylene solution showed an excellent catalytic performance in the synthesis of the $\beta$-lactone $\mathbf{4 c b}$ which was generated with high chemoselectivity (Table 3 , entry 2 ). When the same reactions was carried out in the presence of $\mathrm{Rh} / \mathrm{C}$, as expected, a lower reaction rate was observed (Table 3, entry 3 ); however the supported catalyst resulted more active and selective towards the formation of the lactone ring than $\mathrm{Rh}_{4}(\mathrm{CO})_{12}$ used as reference catalyst (Table 3 , entry 3 vs. 1 ).

It is important to notice that the supported derived catalyst $\mathrm{Rh} / \mathrm{C}$ is stable at room temperature and can be handled at open air, allowing an easy experimental procedure, while $\mathrm{Rh} /$ mesitylene

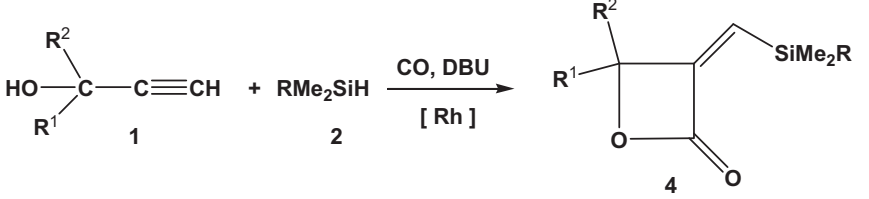

Scheme 4.

Table 3

Silylcarbocyclisation of propargyl alcohols.

\begin{tabular}{|c|c|c|c|c|c|c|c|c|c|c|c|}
\hline Entry $^{\mathrm{a}}$ & 1 & $\mathrm{R}^{1}$ & $\mathrm{R}^{2}$ & 2 & $\mathrm{R}$ & {$[\mathrm{Rh}]$} & $t(\mathrm{~h})$ & 4 & $\begin{array}{l}\text { Conv. } \\
\text { (\%) }\end{array}$ & $\begin{array}{l}\text { Sel. }{ }^{b} \\
(\%)\end{array}$ & $\mathrm{SA}^{\mathrm{c}}$ \\
\hline 1 & c & $n-\operatorname{Pr}$ & $\mathrm{H}$ & b & $\mathrm{tBu}$ & $\mathrm{Rh}_{4}(\mathrm{CO})_{12}$ & 4 & cb & 80 & 66 & 50 \\
\hline 2 & c & $n$-Pr & $\mathrm{H}$ & b & $\mathrm{tBu}$ & $\mathrm{Rh} /$ mesitylene & 4 & cb & 95 & 87 & 237 \\
\hline 3 & c & $n$-Pr & $\mathrm{H}$ & b & $\mathrm{tBu}$ & $\mathrm{Rh} / \mathrm{C}(\mathrm{MVS})$ & 4 & cb & 53 & 71 & 132 \\
\hline 4 & c & $n$-Pr & $\mathrm{H}$ & $\mathbf{a}$ & $\mathrm{Ph}$ & $\mathrm{Rh} / \mathrm{C}(\mathrm{MVS})$ & 4 & cb & 95 & 48 & 237 \\
\hline 5 & c & $n-\operatorname{Pr}$ & $\mathrm{H}$ & $\mathbf{a}$ & $\mathrm{Ph}$ & $\mathrm{Rh}_{4}(\mathrm{CO})_{12}$ & 4 & cb & 100 & 36 & 62 \\
\hline 6 & $\mathbf{b}$ & Me & Et & $\mathbf{a}$ & $\mathrm{Ph}$ & $\mathrm{Rh}_{4}(\mathrm{CO})_{12}$ & 4 & ba & 100 & 93 & - \\
\hline 7 & b & $\mathrm{Me}$ & Et & $\mathbf{a}$ & $\mathrm{Ph}$ & $\mathrm{Rh} / \mathrm{C}$ (MVS) & 4 & ba & 100 & 90 & - \\
\hline 8 & $\mathbf{b}$ & Me & Et & $\mathbf{a}$ & $\mathrm{Ph}$ & $\mathrm{Rh}_{4}(\mathrm{CO})_{12}$ & 1.5 & ba & 94 & 95 & 157 \\
\hline 9 & b & $\mathrm{Me}$ & Et & $\mathbf{a}$ & $\mathrm{Ph}$ & $\mathrm{Rh} / \mathrm{C}(\mathrm{MVS})$ & 1.5 & ba & 87 & 92 & 580 \\
\hline 10 & $\mathbf{b}$ & Me & Et & $\mathbf{a}$ & $\mathrm{Ph}$ & $\mathrm{Rh} / \mathrm{Fe}_{2} \mathrm{O}_{3}$ (MVS) & 1.5 & ba & 60 & 86 & 400 \\
\hline 11 & b & $\mathrm{Me}$ & Et & $\mathbf{a}$ & $\mathrm{Ph}$ & Rh/PBI (MVS) & 1.5 & ba & 51 & 89 & 340 \\
\hline 12 & b & $\mathrm{Me}$ & Et & $\mathbf{a}$ & $\mathrm{Ph}$ & $\mathrm{Rh} / \gamma-\mathrm{Al}_{2} \mathrm{O}_{3}(\mathrm{MVS})$ & 1.5 & ba & 36 & 87 & 240 \\
\hline 13 & $\mathbf{b}$ & Me & Et & $\mathbf{a}$ & $\mathrm{Ph}$ & $\mathrm{Rh} / \mathrm{C}$ (comm.) & 1.5 & ba & 34 & 81 & 227 \\
\hline 14 & d & $\mathrm{Me}$ & $t-\mathrm{Bu}$ & $\mathbf{a}$ & $\mathrm{Ph}$ & $\mathrm{Rh} / \mathrm{C}(\mathrm{MVS})$ & 1.5 & da & 75 & 96 & 500 \\
\hline 15 & d & $\mathrm{Me}$ & $t-\mathrm{Bu}$ & $\mathbf{a}$ & $\mathrm{Ph}$ & $\mathrm{Rh} / \mathrm{C}$ (MVS) & 4 & da & 96 & 97 & - \\
\hline 16 & $\mathbf{e}$ & $-(\mathrm{CH}$ & $2)_{6}-$ & $\mathbf{a}$ & $\mathrm{Ph}$ & $\mathrm{Rh} / \mathrm{C}$ (MVS) & 6 & ea & 100 & 96 & - \\
\hline
\end{tabular}

a Reaction conditions: $3 \mathrm{mmol}$ of $\mathrm{RMe}_{2} \mathrm{SiH}, 3 \mathrm{mmol}$ of alkyne, $3 \times 10^{-3} \mathrm{mmol}$ of $\mathrm{Rh}, 3 \mathrm{~mL}$ of $\mathrm{CH}_{2} \mathrm{Cl}_{2} 0.3 \mathrm{mmol}$ of $\mathrm{DBU}, 100{ }^{\circ} \mathrm{C}, 30 \mathrm{~atm} \mathrm{CO}$; silylformylation byproducts were detected by ${ }^{1} \mathrm{H}$ NMR spectroscopy.

b Determined by GLC and ${ }^{1} \mathrm{H}$ NMR spectroscopic analysis of the reaction mixture after work up.

c SA: [mmol(silane)/mgat Rh·time of reaction(h)] conv.\%. 

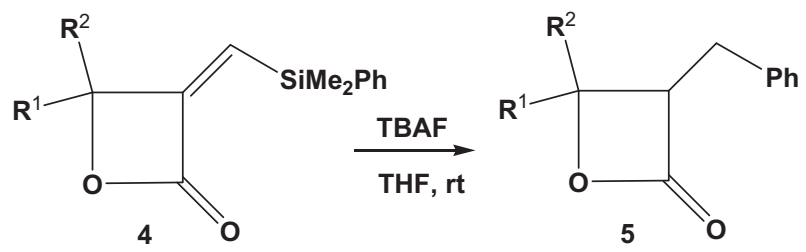

Scheme 5.

solution must be kept at $-40^{\circ} \mathrm{C}$ to avoid decomposition of the SMA and must be manipulated under argon.

Finally, even if $t$-BuMe $2 \mathrm{SiH}$ seems to favour the cyclisation process (Table 3, entries $1-3$ vs. 4,5), the use of $\mathrm{Me}_{2} \mathrm{PhSiH}$ is to be preferred in the synthesis of the $\beta$-lactones since in this case the silyl moiety can be easily removed by fluoride promoted rearrangements generating $\alpha$-methylphenyl- $\beta$-lactones (Scheme 5) [38].

Unfortunately, the silylcarbocyclisation reactions performed with dimethylphenylsilane were characterised by a loss of chemoselectivity towards the $\beta$-lactone ring and relevant yield of the corresponding $\beta$-silylalkenals was observed (Table 3, entries 4 and $5)$. However, MVS Rh/C catalyst confirmed its better chemoselectivity and higher specific activity than the $\mathrm{Rh}_{4}(\mathrm{CO})_{12}$ (Table 3, entry 4 vs. 5).

The steric requirements of the silylcarbocyclisation reactions were respected using 3-dialkylpropargyl alcohols $\mathbf{1 b}, \mathbf{d}, \mathbf{e}$ as reported in entries $6-16$ of Table 3 . Initially, the rhodium catalysts were tested in the silylcarbocyclisation of 3-methyl-1-pentyn-3-ol 1b that had already been successfully submitted to the silylformylation process in the presence of $\mathrm{Me}_{2} \mathrm{PhSiH}$ (Table 2, entries 9 and 10). By comparing Rh/C (MVS) with $\mathrm{Rh}_{4}(\mathrm{CO})_{12}$ (Table 3, entries 6 and 7) we could observe that quantitative conversion of the reagents was obtained after $4 \mathrm{~h}$ and that both catalysts yielded the expected $\beta$-lactones with high chemoselectivity ( $>90 \%$ ).

Subsequently, in order to investigate the catalytic performances of the supported catalysts, the reactions were stopped after $1.5 \mathrm{~h}$ and the specific activity of the rhodium species was calculated. As it is evident from the data reported in Table 3 (entries 9-12), all the supported rhodium species prepared according to the MVS methodology displayed specific activities higher than $\mathrm{Rh}_{4}(\mathrm{CO})_{12}$. The nature of the support plays a fundamental role on the catalytic behaviour: while $\mathrm{Rh} / \mathrm{C}$ (MVS) was indubitably the best catalytic species, $\mathrm{Rh} / \gamma-\mathrm{Al}_{2} \mathrm{O}_{3}$ (MVS) promoted the cyclisation reaction more slowly, but resulted a better catalyst than the commercial $\mathrm{Rh} / \mathrm{C}$ in terms of conversion and selectivity (Table 3, entries 9 and 12 vs. entry 13).

Particularly interesting resulted the catalytic efficiency showed by the rhodium nanoparticles deposited on the polymeric matrix PBI (Table 3, entry 11), a thermooxidatively stable material (up to $600{ }^{\circ} \mathrm{C}$ ) encouraging support for catalytic species [75]. Indeed, Rh/ PBI showed an SA more than twice the specific activity of $\mathrm{Rh}_{4}(\mathrm{CO})_{12}$.

The promising results of specific activity obtained for the MVS nanostructured catalysts can be reasonably related to the morphological properties of the metal nanoparticles obtained by means of this technique, i.e. very small mean diameter and narrow size distribution ( $d_{\mathrm{m}} \approx 1-2 \mathrm{~nm}$, Table 1, entries 3-6). Indeed, in the case of $\mathrm{Rh} / \mathrm{C}$ purchased by Engelhardt and characterised by rhodium nanoparticles with a larger mean diameter and a wider size distribution (Table 1 , entry 1 vs. 3) a dramatic reduction of catalytic activity in the silylcarbocyclisation reaction of 3-methyl-1-pentyn-3ol 1b was observed (less than an half than the corresponding MVS species), together with a remarkable loss of chemoselectivity towards the $\beta$-lactone product 4 ba (Table 3, entry 9 vs. 13 ).

The good catalytic efficiency of Rh/C (MVS) was confirmed by the results obtained in the synthesis of $\beta$-lactones 4da and 4ea

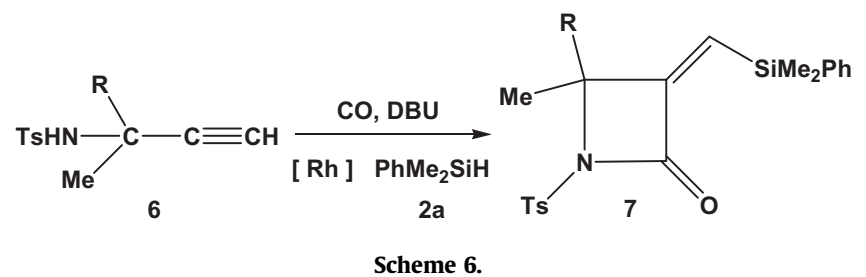

Table 4

Silylcarbocyclisation of $p$-toluensulphonamides with $\mathrm{Me}_{2} \mathrm{PhSiH}$ (2a).

\begin{tabular}{|c|c|c|c|c|c|c|c|c|}
\hline Entry $^{\mathrm{a}}$ & $\mathrm{R}$ & 6 & {$[\mathrm{Rh}]$} & $t(\mathrm{~h})$ & 7 & $\begin{array}{l}\text { Conv. } \\
(\%)^{b}\end{array}$ & $\begin{array}{l}\text { Sel. } \\
(\%)^{b}\end{array}$ & $\mathrm{SA}^{\mathrm{c}}$ \\
\hline 1 & Et & $\mathbf{a}$ & $\mathrm{Rh}_{4}(\mathrm{CO})_{12}$ & 4 & aa & 100 & 96 & - \\
\hline 2 & Et & $\mathbf{a}$ & $\mathrm{Rh} / \mathrm{C}(\mathrm{MVS})$ & 4 & aa & 98 & 90 & - \\
\hline 3 & Et & $\mathbf{a}$ & $\mathrm{Rh} / \mathrm{Fe}_{2} \mathrm{O}_{3}(\mathrm{MVS})$ & 4 & aa & 96 & 86 & - \\
\hline 4 & Et & $\mathbf{a}$ & $\mathrm{Rh} / \gamma-\mathrm{Al}_{2} \mathrm{O}_{3}(\mathrm{MVS})$ & 4 & aa & 27 & 89 & - \\
\hline 5 & Et & $\mathbf{a}$ & $\mathrm{Rh}_{4}(\mathrm{CO})_{12}$ & 1.5 & aa & 28 & 81 & 47 \\
\hline 6 & Et & $\mathbf{a}$ & $\mathrm{Rh} / \mathrm{C}(\mathrm{MVS})$ & 1.5 & aa & 17 & 89 & 113 \\
\hline 7 & Et & $\mathbf{a}$ & $\mathrm{Rh} / \mathrm{Fe}_{2} \mathrm{O}_{3}$ (MVS) & 1.5 & aa & 16 & 78 & 107 \\
\hline 8 & Et & $\mathbf{a}$ & $\mathrm{Rh} / \gamma-\mathrm{Al}_{2} \mathrm{O}_{3}(\mathrm{MVS})$ & 1.5 & aa & 12 & 92 & 80 \\
\hline 9 & Et & $\mathbf{a}$ & Rh/PBI (MVS) & 1.5 & aa & 12 & 89 & 80 \\
\hline 10 & Et & $\mathbf{a}$ & $\mathrm{Rh} / \mathrm{C}$ (comm.) & 1.5 & aa & 6 & 95 & 40 \\
\hline 11 & Et & $\mathbf{a}$ & $\mathrm{Rh} / \gamma-\mathrm{Al}_{2} \mathrm{O}_{3}$ (comm.) & 1.5 & aa & 0 & - & - \\
\hline 12 & Me & b & $\mathrm{Rh}_{4}(\mathrm{CO})_{12}$ & 4 & ba & 94 & 94 & - \\
\hline 13 & Me & b & $\mathrm{Rh} / \mathrm{C}(\mathrm{MVS})$ & 4 & ba & 94 & 91 & - \\
\hline 14 & Me & b & $\mathrm{Rh} / \mathrm{C}$ (MVS) & 1.5 & ba & 32 & 99 & 213 \\
\hline 15 & Me & b & $\mathrm{Rh} / \gamma-\mathrm{Al}_{2} \mathrm{O}_{3}(\mathrm{MVS})$ & 4 & ba & 33 & 96 & 81 \\
\hline 16 & $t-\mathrm{Bu}$ & c & $\mathrm{Rh}_{4}(\mathrm{CO})_{12}$ & 4 & ca & 65 & 100 & 41 \\
\hline 17 & $t-\mathrm{Bu}$ & c & $\mathrm{Rh} / \mathrm{C}(\mathrm{MVS})$ & 4 & ca & 75 & 100 & 187 \\
\hline
\end{tabular}

${ }^{a}$ Reaction conditions: $3 \mathrm{mmol}$ of $\mathrm{Me}_{2} \mathrm{PhSiH}, 3 \mathrm{mmol}$ of alkyne, $3 \times 10^{-3} \mathrm{mmol}$ of $\mathrm{Rh}, 3 \mathrm{~mL}$ of $\mathrm{CH}_{2} \mathrm{Cl}_{2}, 0.3 \mathrm{mmol}$ of DBU, $100{ }^{\circ} \mathrm{C}, 30 \mathrm{~atm} \mathrm{CO}$; small amounts of $(Z)-\beta$ silylalkenals were detected by ${ }^{1} \mathrm{H}$ NMR spectroscopy.

${ }^{b}$ Determined by GLC and ${ }^{1} \mathrm{H}$ NMR spectroscopic analysis of the reaction mixture after work up.

c SA: [mmol(silane)/mgat Rh·time of reaction(h)] conv.\%.

(Table 3, entries 14-16) from their precursors 3,4,4-trimethyl-1pentyn-3-ol 1d and 1-ethynylcyclohexanol 1e which yielded the desired products almost quantitatively and with excellent chemoselectivity (>95\%).

\subsection{Silylcarbocyclisation of propagyl amides: synthesis of $\beta$ - lactams}

Prompted by the good results obtained in the synthesis of $\beta$ lactones, we tested our supported catalysts in the silylcarbocyclisation of $p$-toluensulphonamides in order to prepare $\beta$-lactam rings. Initially $N$-(1-methyl-1-ethyl-2-propynyl)-p-toluensulphonamide $\mathbf{6 a}$ was chosen as model substrate and reacted with equimolar amount of $\mathrm{Me}_{2} \mathrm{PhSiH} \mathbf{2 a}, 10 \mathrm{~mol} \%$ of DBU, in the presence of $0.1 \mathrm{~mol} \%$ of rhodium catalyst, under $30 \mathrm{~atm}$ of $\mathrm{CO}$, at $100^{\circ} \mathrm{C}$ for $4 \mathrm{~h}$ (Scheme 6, Table 4, entries 1-11)

Supported species $\mathrm{Rh} / \mathrm{C}, \mathrm{Rh} / \mathrm{Fe}_{2} \mathrm{O}_{3}$ and $\mathrm{Rh} / \gamma-\mathrm{Al}_{2} \mathrm{O}_{3}$, prepared according to MVS technique, were able to promote the cyclisation reaction with almost total chemoselectivity towards the $\beta$-lactam 7aa (Table 4, entries $2-4$ ). The reaction rate resulted dependent on the nature of the support: after $4 \mathrm{~h}, \mathrm{Rh} / \gamma-\mathrm{Al}_{2} \mathrm{O}_{3}$ afforded the $\beta$ lactam derivative with a conversion much lower than $\mathrm{Rh} / \mathrm{C}$ and $\mathrm{Rh} /$ $\mathrm{Fe}_{2} \mathrm{O}_{3}$ which showed catalytic performances comparable to $\mathrm{Rh}_{4}(\mathrm{CO})_{12}$, taken as homogeneous reference catalyst (Table 4, entry 1 vs. entries $2-4$ ).

To get a deeper insight into the catalytic behaviour of the supported rhodium species, we compared the specific activity (SA) of the catalysts at low conversion of the reagents (i.e. after $1.5 \mathrm{~h}$ ). Analogously to what observed in the silylcarbocyclisation of 
propargyl alcohols $\mathbf{1 b}, \mathbf{d}, \mathbf{e}$ (Table 3), it is clear from the data reported in Table 4 (entries 7-9) that all the MVS catalysts resulted more reactive than $\mathrm{Rh}_{4}(\mathrm{CO})_{12}$ and that MVS Rh/C appeared to be the best catalytic system (entry 6). Rhodium nanoparticles deposited on $\mathrm{Fe}_{2} \mathrm{O}_{3}$ and $\gamma-\mathrm{Al}_{2} \mathrm{O}_{3}$ and on the organic matrix PBI showed good specific activities too (Table 4, entries 7 and 9), thus confirming the importance of the catalyst morphology, i.e. small particles homogeneously dispersed on the support. Indeed, commercial $\mathrm{Rh} / \mathrm{C} \mathrm{5 \%}$ characterised by larger rhodium clusters promoted the formation of 7aa three times slower than the corresponding MVS species (Table 4, entry 6 vs.10) and commercial $\mathrm{Rh} / \gamma-\mathrm{Al}_{2} \mathrm{O}_{3}$ resulted totally inert (Table 4 , entry 11 ).

The good efficiencies and chemoselectivities towards the synthesis of $\beta$-lactam ring showed by the MVS derived catalysts was confirmed by the reactions of $\mathrm{Me}_{2} \mathrm{PhSiH} \mathbf{2 a}$ with alkynes $\mathbf{6 b}$ and $\mathbf{6 c}$ (Table 4, entries 13-17). Again, $\mathrm{Rh} / \mathrm{C}$ resulted the best choice in terms of specific activity (entries 13 and 17) affording the desired $\beta$-lactams in high yields, regardless the structural features of the $p$ toluensulphonamides.

\subsection{Preliminary investigation on the nature of the catalytically active species}

To obtain more information on the characteristics of the real species catalytically active in the silylcarbocyclisation reactions, we performed two experiments reacting, respectively, 3-methyl-1pentyn-3-ol 1b and $N$-(1-methyl-1-ethyl-2-propinyl)-p-toluensulphonamide 6a under the usual experimental conditions (equimolar amount of $\mathrm{Me}_{2} \mathrm{PhSiH}, 10 \mathrm{~mol} \%$ of $\mathrm{DBU}, 100{ }^{\circ} \mathrm{C}, 30 \mathrm{~atm}$ of $\mathrm{CO}$ ) in the presence of $0.1 \mathrm{~mol} \%$ of $\mathrm{Rh} / \mathrm{C}$ (MVS). After $4 \mathrm{~h}$, the CO pressure was discharged and the reaction mixture was filtered through a Teflon filter $(0.2 \mu \mathrm{m})$ in order to remove all suspended metal and/or carbon particles. Then, the clear solutions obtained were added with fresh reagents $\left(3 \mathrm{mmol}\right.$ of acetylenes, $3 \mathrm{mmol}$ of $\mathrm{Me}_{2} \mathrm{PhSiH}$, $0.3 \mathrm{mmol}$ of DBU and $3 \mathrm{~mL}$ of $\mathrm{CH}_{2} \mathrm{Cl}_{2}$ ) and reintroduced into autoclaves. The reaction mixtures were reacted for further $4 \mathrm{~h}$ at $100{ }^{\circ} \mathrm{C}$ under $30 \mathrm{~atm}$ of carbon monoxide (Scheme 7, path a). Contemporaneously, two blank experiments of silylcarbocyclisations of $\mathbf{1 b}$ and $\mathbf{6 a}$ were carried out under the usual experimental conditions affording the corresponding $\beta$-lactone and $\beta$-lactam in high yields and selectivity (Scheme 7, path b).

The obtained data are described in Fig. 3. The conversions of the alkyne derivatives (98-100\%) $\mathbf{1 b}$ and $\mathbf{6 a}$ in the blank experiments are reported in columns 1 and 3, respectively, while columns 2 and 4 indicate the data obtained in the leaching tests.

In the leaching procedures (i.e. recharging tests), after usual work up, both chromatographic and spectroscopic analyses indicated a complete consumption of the reagents (100\%) and a high selectivity towards the $\beta$-lactone $\mathbf{4 b a}$ and the $\beta$-lactam 7aa. Since all rhodium particles supported on carbon should have been removed from the crude products during the filtration step (Scheme 7, path a, step 2), the obtained results clearly indicate the presence of soluble catalytically active metal nanoparticles in the filtered solutions. We can conclude that the Rh/C (MVS) system behaves not as a heterogeneous catalyst but as a source of homogeneous rhodium nanoparticles that represent the real active species. The lower catalytic performances observed for the solvated rhodium atoms deposited on the metal oxides $\left(\mathrm{Rh} / \gamma-\mathrm{Al}_{2} \mathrm{O}_{3}\right.$ and $\mathrm{Rh} /$
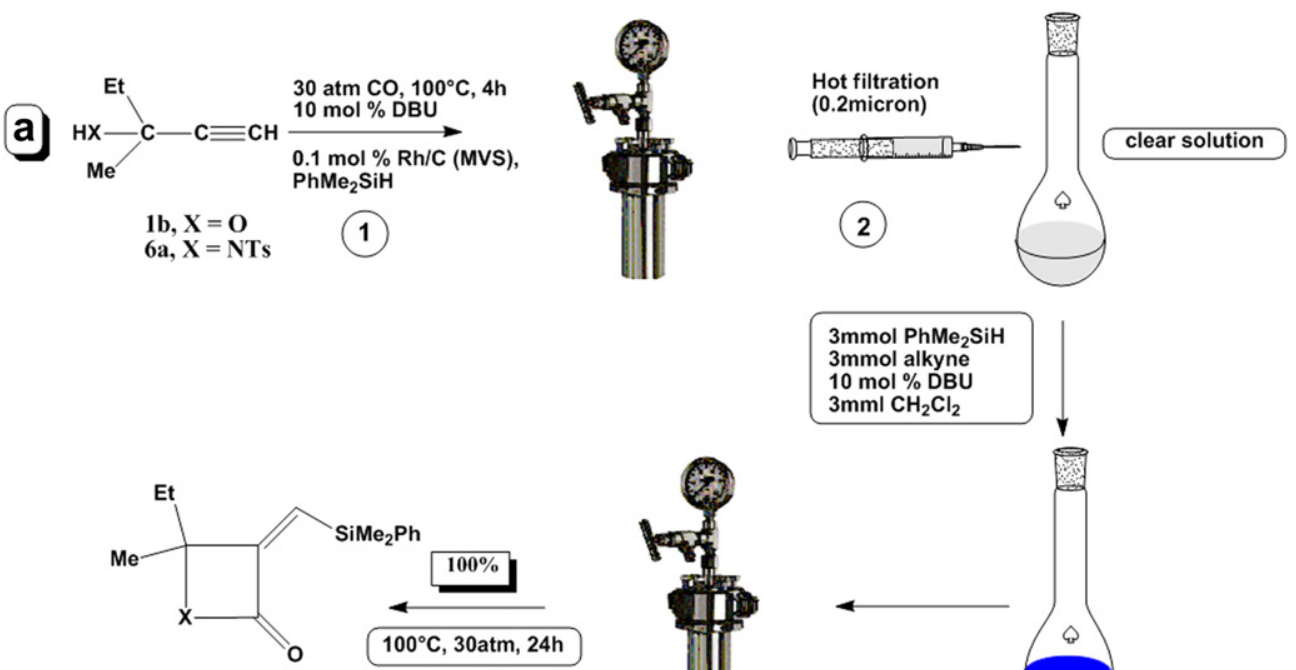

4ba, $X=O \quad$ (sel. 92\%)

7aa, $X=$ NTs (sel. 94\%)
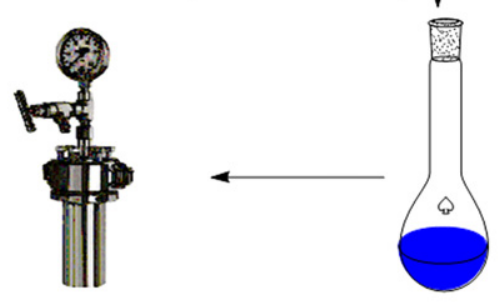

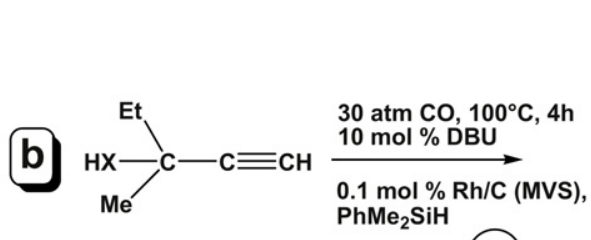

(1)
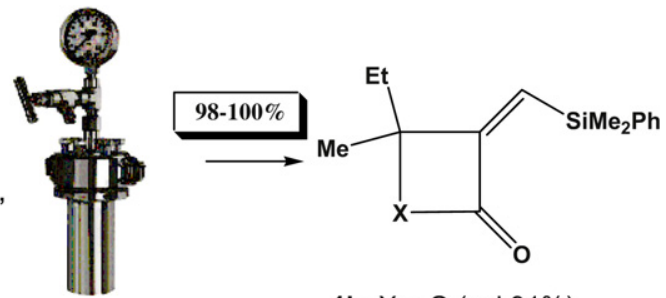

1b, $X=O$ (sel $91 \%$ )

6a, $X=$ NTs (sel 88\%)

Scheme 7. 


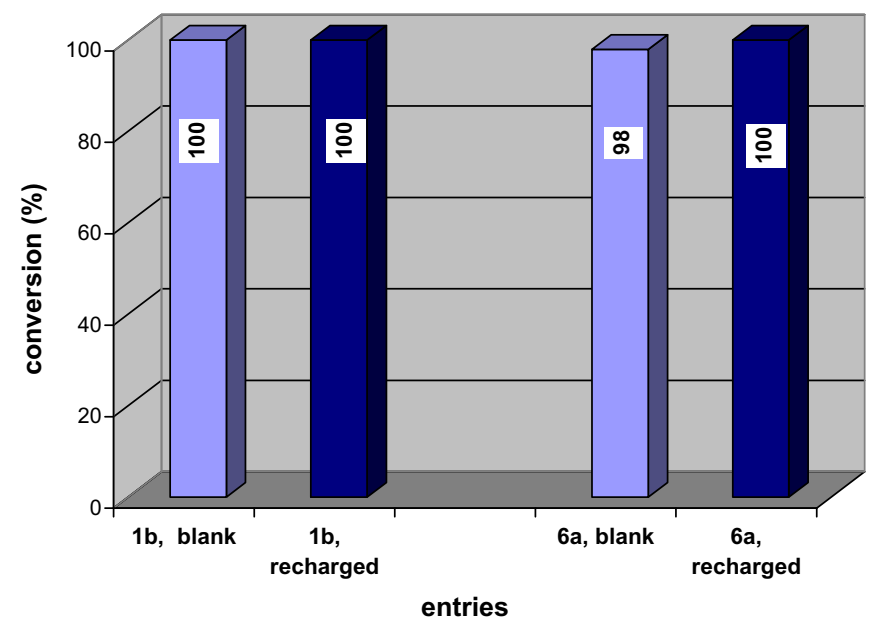

Fig. 3. Results of leaching tests.

$\mathrm{Fe}_{2} \mathrm{O}_{3}$ ) and on polybenzoimidazole ( $\mathrm{Rh} / \mathrm{PBI}$ ) could be related to a minor amount of rhodium leached from these matrices due to their stronger bonds with the metal particles. Moreover, while very small "naked" particles of rhodium are leached from the MVS catalysts, the larger dimensions of commercial rhodium deposited on carbon and alumina could account for the lower specific activities observed in these cases.

\section{Conclusions}

In this paper we have demonstrated that MVS derived rhodium nanoparticles supported on inorganic and organic matrices are able to promote silylcarbocyclisation reactions thus generating $\beta$-lactones and $\beta$-lactams in high yields. Among the prepared catalysts, MVS Rh/C resulted the best choice in terms of activity and selectivity. Besides, all the other MVS species showed a specific activity much better than the corresponding commercial catalysts $\mathrm{Rh} / \mathrm{C}$ and $\mathrm{Rh} / \gamma-\mathrm{Al}_{2} \mathrm{O}_{3}$ and also than $\mathrm{Rh}_{4}(\mathrm{CO})_{12}$ chosen as homogeneous reference species. The good efficiencies observed with the MVS catalysts seem to be related to their structural features, i.e. very small rhodium particles well dispersed on the support. The minor specific activity observed in the cases of metal particles deposited on polar matrices such as PBI and $\mathrm{Fe}_{2} \mathrm{O}_{3}$ could be due to stronger interactions between the rhodium nanoclusters and the support. As a matter of fact, preliminary experiments on $\mathrm{Rh} / \mathrm{C}$ aimed to investigate the real nature of the catalytic species unfortunately showed a remarkable leaching of rhodium from carbon into solution. We can conclude that $\mathrm{Rh} / \mathrm{C}$, and reasonably all MVS supported catalysts, acts as a reservoir, stable with ageing at room temperature, of very active nanoparticles that are released from the support under the reaction conditions.

\section{Experimental}

\subsection{General}

All operations involving the MVS products were performed under a dry argon atmosphere. The co-condensation of rhodium and mesitylene was carried out in a static reactor previously described [73]. The "mesitylene-solvated Rh atoms" solution was worked up under argon atmosphere with the use of the standard Schlenk techniques. The amount of rhodium in the solutions was determined by atomic absorption spectrometry in an electrochemically heated graphite furnace with a Perkin Elmer 4100ZL instrument. The limit of detection calculated for rhodium was $2 \mathrm{ppb}$.

$\mathrm{Me}_{2} \mathrm{PhSiH}(\mathbf{2 a}), t-\mathrm{BuMe}_{2} \mathrm{SiH}(\mathbf{2 b}), 1$-hexyne (1a) and propargyl alcohols $\mathbf{1 b}-\mathbf{e}$ were purchased by Sigma-Aldrich and distilled before use. $N$-propargyl-p-toluensulphonamides $\mathbf{5 a - c}$ were prepared as previously reported [50]. Solvents were purified by conventional methods, distilled and stored under argon.

Commercial $\gamma-\mathrm{Al}_{2} \mathrm{O}_{3}$ (Chimet product, type 49, surface area $110 \mathrm{~m}^{2} / \mathrm{g}$, mean particle diameter $3.1 \mu \mathrm{m}$ ), C (Chimet product, surface area $890 \mathrm{~m}^{2} \mathrm{~g}^{-1}$ ), $\mathrm{Fe}_{2} \mathrm{O}_{3}$ (Aldrich product, powder, $99.5 \%$, $1.0 \mu \mathrm{m}$ average particle size, surface area $2.1 \mathrm{~m}^{2} \mathrm{~g}^{-1}$ ), were dried in a static oven before use. Polybenzoimidazole (PBI) in beaded form (250-500 $\mu \mathrm{m}$, surface area $20 \mathrm{~m}^{2} \mathrm{~g}^{-1}$ ) was gently provided from Prof. B. Corain (University of Padova).

Commercial $\mathrm{Rh} / \gamma-\mathrm{Al}_{2} \mathrm{O}_{3}$ (5 wt.\% of $\mathrm{Rh}$, surface area $130 \mathrm{~m}^{2} / \mathrm{g}$ ) and $\mathrm{Rh} / \mathrm{C}\left(5 \mathrm{wt} . \%\right.$ of $\mathrm{Rh}$, surface area $900 \mathrm{~m}^{2} / \mathrm{g}$ ) were Engelhardt products. $\mathrm{Rh}_{4}(\mathrm{CO})_{12}$ was prepared as previously described [76].

The GLC analyses were performed on a Perkin-Elmer Auto System gas chromatograph, equipped with a flame ionization detector (FID), using a $\mathrm{SiO}_{2}$ column (DB1, $30 \mathrm{~m} \times 0.52 \mathrm{~mm}, 5 \mu \mathrm{m}$ ) and helium as carrier gas.

\subsection{Preparation of rhodium catalysts}

\subsubsection{Synthesis of solvated Rh atoms}

In a typical experiment, rhodium vapour, generated by resistive heating of a tungsten wire surface coated with electrodeposited rhodium (110 mg), was co-condensed at liquid nitrogen temperature with mesitylene $(45 \mathrm{ml})$ in the glass reactor chamber of the MVS apparatus in ca. $45 \mathrm{~min}$. The reactor chamber was warmed to the melting point of the solid matrix (ca. $-30 /-40^{\circ} \mathrm{C}$ ) and the resulting red-brown solution was siphoned at low temperature in a Schlenk tube and kept in a refrigerator at $-20^{\circ} \mathrm{C}$. The content of the metal solution was $1 \mathrm{mg}$ rhodium $/ \mathrm{ml}(0.097 \mathrm{mg}$ atom $/ \mathrm{ml})$.

\subsubsection{Preparation of $\mathrm{Rh} / \gamma-\mathrm{Al}_{2} \mathrm{O}_{3}$ catalyst ( $\left.1 \% \mathrm{w} / \mathrm{w}\right)$}

The $\mathrm{Rh} /$ mesitylene reaction solution ( $5 \mathrm{ml}, 5 \mathrm{mg} \mathrm{Rh}$ ) was added to a suspension of $\gamma-\mathrm{Al}_{2} \mathrm{O}_{3}(500 \mathrm{mg})$ in mesitylene $(10 \mathrm{ml})$. The mixture was stirred for $24 \mathrm{~h}$ at room temperature. The colourless solution was removed and the light-brown solid, containing $1 \mathrm{wt} . \%$ $\mathrm{Rh}$, was washed with $n$-pentane and dried under reduced pressure.

\subsubsection{Preparation of $R h / C$ catalyst $(1 \% w / w)$}

The $\mathrm{Rh} /$ mesitylene reaction solution ( $5 \mathrm{ml}, 5 \mathrm{mg} \mathrm{Rh}$ ) was added to a suspension of carbon $(500 \mathrm{mg})$ in mesitylene $(10 \mathrm{ml})$. The mixture was stirred for $24 \mathrm{~h}$ at room temperature. The colourless solution was removed and the light-brown solid, containing $1 \mathrm{wt} . \%$ $\mathrm{Rh}$, was washed with n-pentane and dried under reduced pressure.

\subsubsection{Preparation of $\mathrm{Rh} / \mathrm{Fe}_{2} \mathrm{O}_{3}$ catalyst $(0.98 \% \mathrm{w} / \mathrm{w})$}

The $\mathrm{Rh} /$ mesitylene reaction solution $(4.9 \mathrm{ml}, 4.9 \mathrm{mg} \mathrm{Rh})$ was added to a suspension of $\mathrm{Fe}_{2} \mathrm{O}_{3}$ (503 $\mathrm{mg}$ ) in mesitylene $(10 \mathrm{ml})$. The mixture was stirred for 5 days at room temperature. The colourless solution was removed and the solid, containing $0.98 \mathrm{wt} . \% \mathrm{Rh}$, was washed with $n$-pentane and dried under reduced pressure.

\subsubsection{Preparation of $R h / P B I$ catalyst $(0.98 \% w / w)$}

The $\mathrm{Rh} /$ mesitylene reaction solution $(3.9 \mathrm{ml}, 3.9 \mathrm{mg} \mathrm{Rh})$ was added to a suspension of PBI (398 $\mathrm{mg}$ ) in mesitylene $(10 \mathrm{ml})$. The mixture was stirred for 5 days at room temperature then treated with hydrogen. The colourless solution was then removed and the solid, containing $0.98 \mathrm{wt} . \% \mathrm{Rh}$, was washed with $n$-pentane and dried under reduced pressure. 


\subsection{Characterization of the catalysts}

High resolution transmission electron microscopy (HR-TEM) images of the materials (powder grains dispersed on lacey carbon $\mathrm{Cu}$ grids) were obtained using a JEOL 3010-UHR with an acceleration potential of $300 \mathrm{kV}$.

Histograms of the particle size distribution were obtained by considering at least 300 particles on the TEM images and the mean particle diameter $(\mathrm{d} m)$ was calculated as $\mathrm{d} m=\Sigma d_{i} n_{i} / \Sigma n i$, where $n_{i}$ was the number of particles of diameter $d_{i}$.

\subsection{Catalytic reactions}

\subsubsection{Silylformylation reactions}

Silylformylation reactions were run in a $25 \mathrm{~mL}$ stainless steel autoclave fitted with a Teflon inner crucible and a stirring bar. In a typical run, equimolar amounts of $\mathrm{Me}_{2} \mathrm{PhSiH}$ and 1-alkyne, toluene or $\mathrm{CH}_{2} \mathrm{Cl}_{2}(2-3 \mathrm{~mL})$ and $0.1 \mathrm{~mol} \%$ of rhodium catalyst were put under CO atmosphere in a Pyrex "Schlenk" tube. This solution was introduced into the previously evacuated ( 0.1 Torr) autoclave by a steel siphon. The reactor was pressurised with carbon monoxide and the mixture was stirred at the chosen temperature for a specified time. After removal of excess $\mathrm{CO}$ (fume hood), the reaction mixture was diluted with pentane or $\mathrm{CH}_{2} \mathrm{Cl}_{2}$, filtered (Celite) and concentrated by bulb to bulb distillation (1 Torr). The residue was purified by column chromatography on silica gel affording the pure aldehydes [50,72].

\subsubsection{Silylcarbocyclisation reactions}

Catalytic runs were performed in a $25 \mathrm{~mL}$ stainless steel autoclave fitted with a Teflon inner crucible and a stirring bar. In a typical run, $3 \mathrm{mmol}$ of alcohol or amide, $3 \mathrm{~mL}$ of a freshly distilled $\mathrm{CH}_{2} \mathrm{Cl}_{2}, 3 \mathrm{mmol}$ of $\mathrm{R}_{3} \mathrm{SiH}, 0.3 \mathrm{mmol}$ of DBU were put, via syringe and under $\mathrm{CO}$ atmosphere, in a Pyrex Schlenk tube. This solution was introduced in the autoclave, previously placed under vacuum $(0.1 \mathrm{mmHg})$ and charged with $0.1 \mathrm{~mol} \%$ of rhodium catalyst, by a steel siphon. The reactor was pressurised to $30 \mathrm{~atm}$ of $\mathrm{CO}$ and stirred at $100{ }^{\circ} \mathrm{C}$ for the required times. The autoclave was then cooled to room temperature and the excess of $\mathrm{CO}$ was removed under fume hood. The reaction mixture was diluted with $\mathrm{CH}_{2} \mathrm{Cl}_{2}$ filtered on silica gel and concentrated under reduced pressure. The reagents conversion and the products composition were determined by GLC and ${ }^{1} \mathrm{H}$ NMR. The purification of the crude oil by column chromatography on silica gel afforded the pure $\beta$-lactones [38] and $\beta$-lactams [50].

\subsubsection{Leaching procedure}

Leaching studies were performed using the hot filtration technique. After $4 \mathrm{~h}$ reaction of a standard catalytic run, the $\mathrm{CO}$ pressure was removed under fume hood, the reaction mixture was filtered at $100{ }^{\circ} \mathrm{C}$ through syringe fitted with a $0.2 \mu \mathrm{m}$ Teflon filter, in order to remove all fine particles. Then $3 \mathrm{mmol}$ of alcohol or amide, $3 \mathrm{~mL}$ of a freshly distilled solvent, $3 \mathrm{mmol}$ of $\mathrm{Me}_{2} \mathrm{PhSiH}, 0.3 \mathrm{mmol}$ of $\mathrm{DBU}$ were added to the clear solution obtained which was introduced into an autoclave by a steel siphon and reacted under the standard reaction conditions for further $4 \mathrm{~h}$. After the usual work up, the reagents conversion and the products composition were determined by GLC and ${ }^{1} \mathrm{H}$ NMR.

\section{Acknowledgements}

This work was partially supported by the Italian Ministry of University and Scientific Research (MIUR) under the PRIN 2008 program (2008SXASBC_001).

\section{References}

[1] A. Bruggink (Ed.), Synthesis of $\beta$-Lactam Antibiotics Chemistry, Biocatalysis and Process Integration, Kluwer, Dordrecht, Netherlands, 2001.

[2] G.S. Singh, Mini-Rev. Med. Chem. 4 (2004) 69-92.

[3] G.S. Singh, Mini-Rev. Med. Chem. 4 (2004) 93-109.

[4] X. Bengang, R. Jianghong, L. Rongrong, Mini-Rev. Med. Chem. 8 (2008) $455-471$.

[5] M. Bassetti, L. Nicolini, S. Esposito, E. Righi, C. Viscoli, Curr. Med. Chem. 16 (2009) 564-575.

[6] K. Murakami, M. Doi, T. Yoshida, J. Antibiot. 35 (1982) 39-45.

[7] D.G. Brenner, J.R. Knowels, Biochemistry 23 (1983) 5839-5846.

[8] D.G. Brenner, J. Org. Chem. 50 (1985) 18-23.

[9] Y.L. Chen, C. Chang, K. Hedberg, K. Guarino, W.M. Welch, L. Kiessling, J. Antibiot. 40 (1987) 803-822.

[10] I.S. Bennett, NJ.P. Broom, K. Coleman, S. Coulton, P.D. Edwards, I. Francois, D.R.J. Griffin, N.F. Osborne, P.M. Woodall, J. Antibiot. 44 (1991) 338-343.

[11] M. Imuta, S. Uyeo, T. Yoshida, Chem. Pharm. Bull. 39 (1991) 658-662.

[12] S. Adam, R. Then, P. Angehrn, J. Antibiot. 45 (1992) 587-588.

[13] C. Im, S.N. Maiti, R.G. Micetich, M. Daneshtalab, K. Atchison, O.A. Phillips, C. Kunugita, J. Antibiot. 47 (1994) 1030-1040.

[14] C. Michaux, P. Charlier, J.M. Frere, J. Wouters, J. Am. Chem. Soc. 127 (2005) 3262-3263.

[15] S.N. Maiti, R.P. Kamalesh Babu, R. Shan, Top. Heterocycl. Chem. 2 (2006) 207-246.

[16] T.S. Mansour, A. Agarwal, A. Venkatesan, T. Abe, A. Mihira, T. Takasaki, K. Sato, H. Ushirogochi, I. Yamamura, T. Isoda, Z. Li, Y. Yang, T. Kumagai, Chem. Med. Chem. 2 (2007) 1713-1716.

[17] F.J. Perez-Llarena, G. Bou, Curr. Med. Chem. 16 (2009) 3740-3765.

[18] D.H. Kim, K.B. Kim, J. Am. Chem. Soc. 113 (1991) 3200-3202.

[19] M. Yun, C. Park, S. Kim, D. Nam, S.C. Kim, D.H. Kim, J. Am. Chem. Soc. 114 (1992) 2281-2282.

[20] D.H. Kim, Bioorg. Med. Chem. Lett. 3 (1993) 1313-1318.

[21] D.H. Kim, Z.- H.Li, Bioorg. Med. Chem. Lett. 4 (1994) 2297-2302.

[22] D.H. Kim, J.J. Ryoo, Bioorg. Med. Chem. Lett. 5 (1995) 1287-1292.

[23] K. Bell, E. Saepudin, P. Harrison, Can. J. Chem. 74 (1996) 24-27.

[24] D. Romo, P.H.M. Harrison, S.I. Jenkins, R.W. Riddoch, K. Park, H.W. Yang, C. Zhao, G.D. Wright, Bioorg. Med. Chem. Lett. 6 (1998) 1255-1260.

[25] M.S. Lall, C. Karvellas, J.C. Vederas, Org. Lett. 5 (1999) 803-806.

[26] H. Kim, J. Park, S.J. Chung, J.D. Park, N.-K. Park, J.H. Han, Bioorg. Med. Chem. Lett. 10 (2002) 2553-2556.

[27] M.S. Lall, Y.K. Ramtohul, M.N.G. James, J.C. Vederas, J. Org. Chem. 67 (2002) $1536-1547$.

[28] J. Yin, E.M. Bergman, M.M. Cherney, M.S. Lall, R.P. Jain, J.C. Vederas, M.N.G. James, J. Mol. Biol. 354 (2005) 854-871.

[29] T. Bottcher, S.A. Sieber, Angew. Chem., Int. Ed. 47 (2008) 4600-4603.

[30] S. Prosch, H.D. Volk, D. Kruger, Universitat zu Berlin Technologiestrans Ferstelle, WO 2004004749 A1, 2004.

[31] S. Sieber, T. Boettcher, Univ. Muenchen L. Maximilians, WO 2009106211 A1, 2009.

[32] H. Sadanari, J. Tanaka, Z. Li, R. Yamada, K. Matsubara, T. Murayama, Virus Res. 141 (2009) 68-77.

[33] W. Adam, A. Reiner, N.D. Grau, L. Hasemann, B. Nestler, E.M. Peters, K. Peters, F. Prechtl, H.G. Von Schnering, J. Org. Chem. 56 (1991) 5778-5781.

[34] W. Adam, A. Reiner, L. Hasemann, V.O. Nada Salvado, B. Nestler, E.M. Peters, K. Peters, F. Prechtl, H.G. Von Schnering, J. Org. Chem. 56 (1991) 5782-5785.

[35] V.O. Nada Salvado, E.M. Peters, K. Peters, H.G. Von Schnering, W. Adam, J. Org. Chem. 60 (1995) 3879-3886.

[36] W. Adam, V.O. Nada Salvado, J. Org. Chem. 60 (1995) 578-584

[37] S. Ma, X. Jiang, X. Cheng, H. Hou, Adv. Synth. Catal. 348 (2006) 2114-2124.

[38] L.A. Aronica, C. Mazzoni, A.M. Caporusso, Tetrahedron 66 (2010) 265-273.

[39] M.I. Page, A.P. Laws, Tetrahedron 56 (2000) 5631-5638.

[40] B. Alcaide, P. Almendros, Chem. Soc. Rev. 30 (2001) 226-240.

[41] B. Alcaide, P. Almendros, C. Aragoncillo, Chem. Rev. 107 (2007) 4437-4492.

[42] Y. Wang, R.L. Tennyson, D. Romo, Heterocycles 64 (2004) 605-658 and references therein.

[43] S. Robin, G. Rousseau, Eur. J. Org. Chem. (2002) 3099-3114.

[44] A. Brandi, S. Cicchi, F.M. Cordero, Chem. Rev. 108 (2008) 3988-4035.

[45] M.T. Aranda, P. Perez-Faginas, R. Gonzalez-Muniz, Curr. Org. Synth. 6 (2009) 325-341.

[46] I. Matsuda, A. Ogiso, S. Sato, J. Am. Chem. Soc. 112 (1990) 6120-6121.

[47] I. Matsuda, J. Sakakibara, H. Nagashima, Tetrahedron Lett. 32 (1991) 7431-7434.

[48] I. Ojima, Pure Appl. Chem. 74 (2002) 159-166.

[49] G. Varchi, I. Ojima, Curr. Org. Chem. 10 (2006) 1341-1362.

[50] L.A. Aronica, G. Valentini, A.M. Caporusso, P. Salvadori, Tetrahedron 63 (2007) 6843-6854.

[51] S.E. Denmark, J.H. Liu, J. Am. Chem. Soc. 129 (2007) 3737-3744.

[52] L.A. Aronica, A.M. Caporusso, P. Salvadori, Eur. J. Org. Chem. (2008) 3039-3060.

[53] G. Vitulli, P. Salvadori, A. Raffaelli, P.A. Costantino, R. Lazzaroni, J. Organomet. Chem. 239 (1982) C23-C25.

[54] S. Alini, A. Bottino, G. Capannelli, R. Carbone, A. Comite, G. Vitulli, J. Mol. Catal. A: Chem. 206 (2003) 363-370. 
[55] G. Marconi, P. Pertici, C. Evangelisti, A.M. Caporusso, G. Vitulli, G. Capannelli, M. Hoang, T.W. Turney, J. Organomet. Chem. 689 (2004) 639-646.

[56] P. Centomo, M. Zecca, S. Lora, G. Vitulli, A.M. Caporusso, M.L. Tropeano, C. Milone, S. Galvagno, B. Corain, J. Catal. 229 (2005) 283-297.

[57] C. Evangelisti, N. Panziera, M. vitulli, P. Pertici, F. Balzano, G. Uccello-Barretta, P. Salvadori, Appl. Catal., A: Gen. 339 (2008) 84-92.

[58] P. Salvadori, G. Vitulli, A. Raffaelli, R. Lazzaroni, J. Organomet. Chem. 258 (1983) 351-355.

[59] R. Lazzaroni, A. Raffaelli, R. Settambolo, S. Bertozzi, G. Vitelli, J. Mol. Catal. 50 (1989) 1-9.

[60] S. Bertozzi, N. Campigli, G. Vitulli, R. Lazzaroni, P. Salvadori, J. Organomet. Chem. 487 (1995) 41-45.

[61] C. Polizzi, A.M. Caporusso, G. Vitulli, P. Salvadori, J. Organomet. Chem. 451 (1993) C4-C6.

[62] C. Polizzi, A.M. Caporusso, G. Vitulli, P. Salvadori, M. Pasero, J. Mol. Catal. 91 (1994) 83-90.

[63] A.M. Caporusso, S. Barontini, P. Pertici, G. Vitulli, P. Salvatori, J. Organomet. Chem. 564 (1998) 57-59.

[64] A.M. Caporusso, N. Panziera, P. Pertici, E. Pitzalis, P. Salvadori, G. Vitulli, G. Martra, J. Mol. Catal. 150 (1999) 275-285.

[65] G. Uccello-Barretta, F. Balzano, C. Evangelisti, P. Raffa, A. Mandoli, S. Nazzi, G. Vitulli, J. Organomet. Chem. 693 (2008) 1276-1282.
[66] L.A. Aronica, E. Schiavi, C. Evangelisti, A.M. Caporusso, P. Salvadori, G. Vitulli, L. Bertinetti, G. Martra, J. Catal. 266 (2009) 250-257.

[67] A.M. Caporusso, P. Innocenti, L.A. Aronica, G. Vitulli, R. Gallina, A. Biffis, M. Zecca, B. Corain, J. Catal. 234 (2005) 1-13.

[68] N. Panziera, P. Pertici, L. Barazzone, A.M. Caporusso, G. Vitulli, P. Salvadori, S. Borsacchi, M. Geppi, C.A. Veracini, G. Martra, L. Bertinetti, J. Catal. 246 (2007) 351-361.

[69] C. Evangelisti, N. Panziera, P. Pertici, G. Vitulli, P. Salvadori, C. Battocchio, G. Polzonetti, J. Catal. 262 (2009) 287-293.

[70] C. Evangelisti, N. Panziera, A. D’Alessio, L. Bertinetti, M. Botavina, G. Vitulli, J. Catal. 272 (2010) 246-252.

71] L.A. Aronica, A.M. Caporusso, P. Salvadori, Chem. Today 26 (2008) 6-8.

[72] L.A. Aronica, S. Terreni, A.M. Caporusso, P. Salvadori, Eur. J. Org. Chem. 22 (2001) 4321-4329.

[73] G. Vitulli, E. Pitzalis, R. Lazzaroni, P. Pertici, P. Salvadori, O. Salvetti, S. Coluccia, G. Martra, Mater. Sci. Forum 195 (1995) 93.

[74] G. Vitulli, C. Evangelisti, P. Pertici, A.M. Caporusso, N. Panziera, P. Salvadori, M.G. Faga, C. Manfredotti, G. Martra, S. Coluccia, A. Balerna, S. Colonna, S. Mobilio, J. Organomet. Chem. 681 (2003) 37-50.

[75] A.A. D’Archivio, L. Galantini, A. Biffis, K. Jerabek, B. Corain, Chem.-Eur. J. 6 (2000) 794-799.

[76] S. Martinengo, G. Giordano, P. Chini, Inorg. Synth. 28 (1990) 441-449. 